\title{
Small hydropower in Southern Africa - an overview of five countries in the region
}

\author{
Wim Jonker Klunne \\ Council for Scientific \& Industrial Research, Pretoria, South Africa
}

\begin{abstract}
This paper looks at the status of small hydropower in Lesotho, Mozambique, South Africa, Swaziland and Zimbabwe. For each country, an overview will be given of the electricity sector and the role of hydropower, the potential for small hydropower and the expected future of this technology. Small hydropower has played an important role in the history of providing electricity in the region. After a period with limited interest in applications of small hydropower, in all five countries, a range of stakeholders from policy makers to developers are showing a renewed interest in small hydropower. Although different models were followed, all five countries covered in the paper do currently see activities around grid connected small scale hydropower. Particular frameworks that facilitate IPPs and Power Purchase Agreements with the national utility do provide a basis for (local) commercial banks to provide finance. Off-grid hydropower for rural electrification purposes sees activities in the countries with an active (support) role of government in this respect only. Small hydropower, renewable energy technology has large potential across the southern Africa region, both for grid connected and off-grid applications. Historically, small hydropower played an important role in the development of the region. Since the mid-1960s, however, the main emphasis has been on centralised fossil fuel-based electricity generation. Developers and policy makers have only recently begun looking at small hydropower again.
\end{abstract}

Keywords: hydropower, electricity, Africa

\section{Background}

While approximately $10 \%$ of the global hydropower potential is located on the African continent (the majority in Sub-Saharan Africa), only $4-7 \%$ of this huge resource has been developed (ESHA \& IT Power, 2006; Min Conf Water for Agriculture and Energy in Africa, 2008).

Figures stating the potential of hydropower usually refer to large-scale hydropower only. No proper statistics on the potential for small- and microscale hydropower are available for the African continent. Their rates of development are commonly understood to be even lower than for large-scale hydropower. Gaul, et al. (2010) compared the 45 000 plants below $10 \mathrm{MW}$ in China with a total of a few hundred developed sites in the whole of Africa as an indication of the low rate of small hydropower development.

Small hydropower can play a pivotal role in providing energy access to remote areas, either in stand-alone isolated mini-grids or as distributed generation in national grids. A number of national governments and bi- and multilateral donors have recognised the potential role of small hydropower in eradicating energy poverty. An example of this is the World Bank's new energy strategy, which specifically highlights small-scale hydropower as an important component of future World Bank activities in Africa (World Bank, 2010).

Small hydropower projects have been implemented in several countries in the region, but information about these projects is limited and incomplete. While some technical information on the implemented projects is available, information about the success of the implementation models is mostly unavailable (Pigaht \& van der Plas, 2009; Michael, 2008). Basic technical information about existing hydro-stations may be available from different sources, but is incomplete and inconsistent. This lack of information severely hampers the ability to learn from past experiences and creates a barrier to the uptake of the technology (Gaul et al., 2010). 


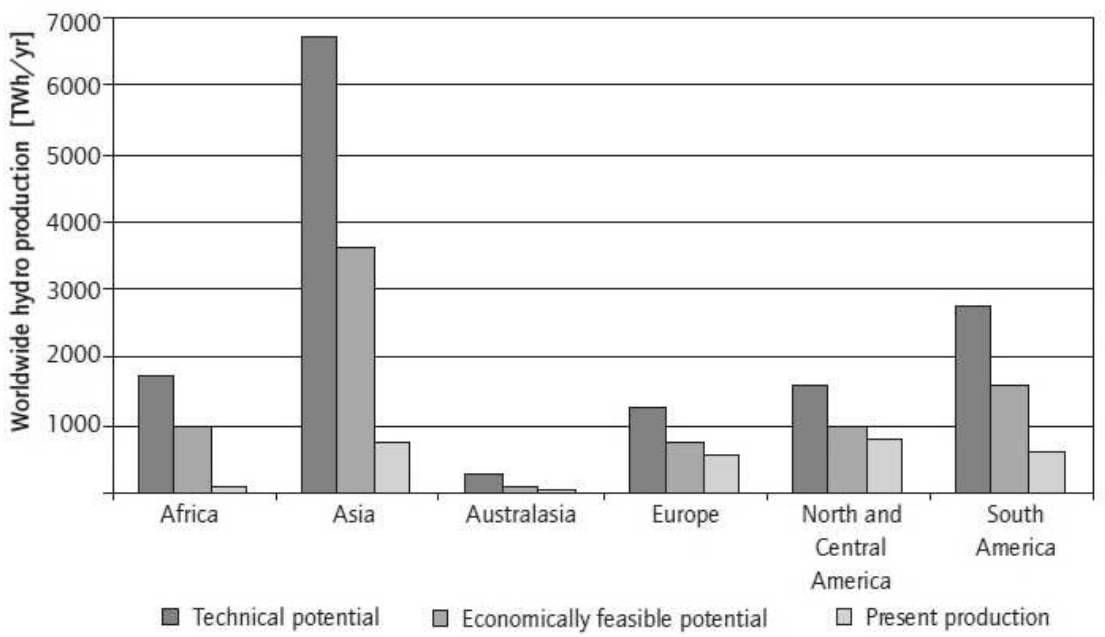

Figure 1: Hydropower potential worldwide

(IEA 2003)

This paper addresses the barrier of lack of information by providing an overview of the status of small hydropower in five southern African countries.

\section{Defining small hydropower}

No internationally agreed definitions exist for the different sizes of hydropower. A generic distinction between 'large' and 'small' hydropower is that the latter can be seen as installations up to $10 \mathrm{MW}$ of installed capacity. Most countries in Sub-Saharan Africa use this limit to define small hydro, although Mozambique uses $25 \mathrm{MW}$ as the upper limit for small hydro (Esser, 2012).

Within the small hydro range, a distinction can be made between mini hydro (maximum $1 \mathrm{MW}$ installed capacity), micro hydro (below 300 or 100 $\mathrm{kW}$ installed capacity) and pico hydro (below 20, 10 or $5 \mathrm{~kW}$ installed capacity). Each of these has its own specific technical characteristics.

In this paper, the upper limit of $10 \mathrm{MW}$ installed capacity is used when referring to small hydropower, micro hydropower refers to installations of below $300 \mathrm{~kW}$ installed capacity - in line with Fraenkel et al. (1991) - and for pico hydro an upper limit of 10 $\mathrm{kW}$ is assumed.

\section{Small hydropower in southern Africa}

Small hydropower is a proven, mature technology with a long track record. Although not well documented, this technology has been playing an important role in earlier electrification efforts in southern Africa. However, interest in the technology faded in the second half of the 20th century mainly due to the increased reach of national grids with cheap and reliable electricity.

The gold mines at Pilgrims' Rest (South Africa), for example, were powered by two $6 \mathrm{~kW}$ hydro turbines as early as 1892 . Two years later, a $45 \mathrm{~kW}$ turbine augmented those turbines to power the first electrical railway in 1894 (Eskom, 2009).

During the 1960s and 70s, church missions in several African countries built small hydropower installations. In Tanzania, for instance, church missions installed more than 16 small hydropower systems that are still operating (Mtalo, 2005), while large-scale commercial farmers in the Eastern Highlands of Zimbabwe installed hydropower stations as early as the 1930s (Klunne, 1993).

A number of countries in Africa recently started to revive the small hydropower sector, either through international development agencies or private sector-led initiatives. New initiatives in central Africa (Rwanda), east Africa (Kenya, Tanzania and Uganda) and southern Africa (Malawi, Mozambique and Zimbabwe) are focusing specifically on implementing small hydropower projects (Jonker Klunne, 2011). In South Africa, the first new grid connected small hydropower station installed in 20 years was opened in 2009, with more under development.

\section{Country overview}

This section summarises the potential and current status of small hydropower in selected countries in southern Africa. While the text describes the hydropower stations in the small hydropower range, an overview of all hydro stations is provided in a table per country. For full technical details of the hydropower stations, the reader is referred to the hydropower database on the author's website (http://hydro4africa.net/HP_database/).

For five countries in the southern part of southern Africa, a brief overview will be given on the electricity sector and the potential for hydropower, after which the current small hydropower systems will be described. This will be followed by an indication of the possible future of small hydropower in each country. 


\section{Lesotho}

The electricity sector in Lesotho is relatively small (3\% of total energy consumed) with an installed capacity of $76 \mathrm{MW}$ only. Main contributor to this installed capacity is the "Muela hydro plant (72 MW), complemented by two small hydro plants, a number of isolated diesel grids and imports from South Africa and Mozambique through the Southern African Power Pool.

Statistics reveal that the national electrification rate in Lesotho in 2009 was $16 \%$, which provided $44 \%$ of the urban population and $6 \%$ of the rural population with electricity (IEA, 2009). The government has set a goal of increasing the electrification rate to $35 \%$ of all households by 2015 and $40 \%$ by 2020 (Government of Lesotho, 2005).

\section{Hydropower potential}

Nearly all locally generated electricity is hydropower-based, mostly from the $72 \mathrm{MW}$ 'Muela plant, which is owned and operated by the Lesotho Highland Development Authority as part of the water transfer system to South Africa. Currently, this is augmented by two small hydropower plants. The Lesotho Highlands Water Project does offer opportunities for more hydropower development and several studies have been conducted on pumpedstorage plants as well.

Estimates indicate that Lesotho's large-scale hydropower potential is approximately $450 \mathrm{MW}$. By 1990, investigations into the potential for smallscale hydropower plants in Lesotho indicated a total capacity of $20 \mathrm{MW}$ at 22 sites for both mini and micro hydropower (Taele et al., 2012).

The French company Sogreah (now part of Artelia) studied nine potential sites in the 100 to 1 $000 \mathrm{~kW}$ range and completed feasibility studies on three preferred sites: Motete, Qacha's Neck and Tlokoeng. In the micro hydropower range, a report by NERCA (1982) estimates a potential of between 20 to 40 feasible sites in the country with an average capacity of $25 \mathrm{~kW}$.

\section{Current systems}

While there are five small-scale hydropower plants in Lesotho, namely Katse (540 kW), Mantsonyane
(2 MW), Semonkong (180 kW), Tlokoeng (670 kW) and Tsoelike $(400 \mathrm{~kW})$, only the Katse and Semonkong plants are currently operational.

The installations at Mantsonyane and Semonkong were both built with Norwegian development assistance and commissioned in 1989. The Mantsonyane system was originally designed to serve the towns of Mantsonyane and Thaba Tseke in island operation, but has since been connected to the grid and used for peak lopping (sad-elec, PPA et al., 2001). The station has been out of operation since it was flooded in 2006 (Grongstad, 2008). Semonkong serves a small community through an isolated mini grid (sad-elec, PPA et al., 2001). This hybrid hydro/diesel system was included in the World Bank-funded electricity sector restructuring project to evaluate private sector operation as a prelude to possible privatisation. However, after this project, the system returned to operation and maintenance by Lesotho's national utility, the Lesotho Electricity Company (LEC).

The systems at Tlokoeng and Tsoelike were developed with French assistance, but both suffered from technical problems and siltation. Both stations have been decommissioned and their service areas connected to the main electricity grid (Taele, et al., 2012).

The Katse system is a small installation in the Katse Dam to provide electricity for the operation of the dam. The system is connected to the LEC grid and has three diesel generators as back-up.

\section{Future for small hydropower}

In a recent article in Renewable Energy, Taele et al., (2012) conclude that the situation in Lesotho is conducive to developing small hydropower systems due to adequate existing hydropower resources and a settlement pattern in rural areas that favours decentralised energy systems. The current legislation that allows independent power producers to generate electricity for the national grid and the creation of a National Rural Electrification Fund by the government is seen by the authors as facilitating the uptake of small hydropower technology.

The reality, however, is that international partners find it difficult to develop viable business mod-

Table 1: Hydropower in Lesotho

(For station details see thtp://hydro4africa.net/ HP_database/country.php?country=Lesotho)

\begin{tabular}{|c|c|c|c|c|}
\hline & Decommissioned & Operational & Under development & Potential site \\
\hline \multicolumn{5}{|l|}{ Pico } \\
\hline Micro & & Semonkong (180 kW) & & \\
\hline Small & $\begin{array}{c}\text { Mantsonyane }(2 \mathrm{MW}) \\
\text { Tlokoeng }(670 \mathrm{~kW}) \\
\text { Tsoelike }(400 \mathrm{~kW})\end{array}$ & Katse $(540 \mathrm{~kW})$ & & \\
\hline Large & & Muela (72 MW) & & $\begin{array}{l}\text { Oxbow (80 MW) } \\
\text { Quithing (15 MW) }\end{array}$ \\
\hline
\end{tabular}


els for the implementation of small hydropower in Lesotho. Efforts by Tarini from India to establish hydropower projects at Oxbow and Quithing have been on-going for a number of years now without any indication that construction can start any time soon. Also the engagement of a private hydro operator from South Africa to operate and maintain the Semonkong station did not result in handing over this responsibility from LEC to this operator after the pilot period ended.

\section{Mozambique}

The installed electricity capacity in Mozambique is 2.308 GW (2009), of which hydropower contributes approximately $99.7 \%$. The electrification rate is only $14 \%$, with an estimated $26 \%$ urban and $5 \%$ rural areas electrified. Mozambique's electricity company, EDM, prepared a Master Plan for the expansion of the country's national power grid and distribution networks to reach $15 \%$ of the population by the year 2020 (Reegle, 2011).

\section{Hydropower potential}

The country's largest hydro potential lies in the Zambezi River basin at sites such as Cahora Bassa North and Mphanda Nkuwa. Currently about 2200 MW generating capacity has been developed. The potential for small hydropower projects, mainly in the Manica, Tete and Niassa provinces (Chambal, 2010), is $190 \mathrm{MW}$. This includes $6 \mathrm{MW}$ of micro hydropower (smaller than $2 \mathrm{MW}$ ), $18 \mathrm{MW}$ of mini hydropower (between 2 and $6 \mathrm{MW}$ ) and $166 \mathrm{MW}$ of small hydropower (between 8 and $15 \mathrm{MW}$ ).

A study of medium-sized and large plants reveals a high potential for small hydropower projects in the central and northern parts of the country, while the south is relatively poor in hydropower resources for energy generation. An energy survey by the National Energy Fund (FUNAE) in 2004 indicated that the tea producing areas in the Zambézia Province also have good hydropower resources.

An Intermediate Technology Development Group (ITDG) publication (Khennas \& Barnett, 2000) gives an overview of the potential of micro hydropower in Mozambique, especially in the Manica Province. A scoping study for micro hydropower investments in the Manica, Niassa and Tete provinces, undertaken for the World Bank's Energy Access and Reform Programme (ERAP) project, identifies the critical issues in developing the hydropower sector (ITDG, 2006).

Mozambique's Policy for Renewable Energy and Master Plan for Off-Grid Electrification (KPMG, 2008) lists 60 identified hydropower locations with a total potential of up to $1000 \mathrm{MW}$, mainly in the Manica Province.

In a recent report on Mozambique by the International Renewable Energy Agency (IRENA) (2012) the main barrier to the development of small hydropower projects in Mozambique is identified as the lack of a framework to support independent power producers.

\section{Current systems}

Currently six hydropower stations are connected to the national grid in Mozambique, while a substantial number of off-grid systems also exist.

Information on the off-grid systems, however, is sparse and incomplete. At least 10 systems, with an installed capacity of around $250 \mathrm{~kW}$, are operational next to three stations at Chiurairue, Majaua and Rotanda currently being developed by FUNAE. Since information on hydropower stations at tea estates, for instance, is not included, these figures probably underestimate the real situation.

Table 2: Hydropower in Mozambique

(For station details see http://hydro4africa.net/ HP_database/country.php?country=Mozambique)

\begin{tabular}{|c|c|c|c|c|}
\hline & Decommissioned & Operational & Under development & Potential site \\
\hline$\overline{P i c o}$ & & Tendayi Zvemapowa $(9.6 \mathrm{~kW})$ & & \\
\hline Micro & & $\begin{array}{c}\text { Chihururu }(22.2 \mathrm{~kW}) \\
\text { Chitofu }(30 \mathrm{~kW}) \\
\text { Honde }(75 \mathrm{~kW}) \\
\text { Jimy }(18 \mathrm{~kW}) \\
\text { Lino }(22 \mathrm{~kW}) \\
\text { Ndiriri }(20 \mathrm{~kW}) \\
\text { Ngwarai }(25 \mathrm{~kW}) \\
\text { Nquarai }(22 \mathrm{~kW}) \\
\text { Tendayi }(14 \mathrm{~kW})\end{array}$ & Chiurairue $(23.1 \mathrm{~kW})$ & \\
\hline Small & & $\begin{array}{l}\text { Cuamba }(1.1 \mathrm{MW}) \\
\text { Lichinga }(750 \mathrm{~kW})\end{array}$ & $\begin{array}{l}\text { Majaua }(530 \mathrm{~kW}) \\
\text { Rotanda }(620 \mathrm{~kW})\end{array}$ & \\
\hline Large & & $\begin{array}{c}\text { Cahora Bassa }(2075 \mathrm{MW}) \\
\text { Chicamba Real }(38.4 \mathrm{MW}) \\
\text { Corumana }(16.6 \mathrm{MW}) \\
\text { Mavuzi }(52 \mathrm{MW})\end{array}$ & Mphanda Nkuwa (1500 MW) & \\
\hline
\end{tabular}


Generally, there is a growing interest in Mozambique to promote the use of small hydropower for isolated rural communities. The 75 $\mathrm{kW}$ Honde scheme, for example, is using small hydropower to electrify a village with 200 households, a health centre, school, two maize mills and shops. The project is being implemented by the Provincial Government of Manica with support from the German Development Agency, GIZ (KPMG, 2008).

In addition to the Government of Mozambique, a number of NGOs and bi-lateral donors are active in micro hydropower in the country. Practical Action and their Mozambican counterpart, Kwaedza Sumukai Manica (KSM), are using the socalled 'generator model' to develop village electrification projects. The model is based on the electrification of a community by a private entrepreneur where the community owns the local transmission and distribution infrastructure (Mutubuki-Makuyana, 2010).

GIZ has also worked with local entrepreneurs to extend their businesses from milling to electricity distribution and has upgraded ten systems, supported the local production of turbines and is currently assisting local education institutes in Chimoio in the Manica Province to set up a local hydropower training and knowledge centre (Villa, 2012).

\section{Future for small hydropower}

Overall, the situation in Mozambique seems favourable for the development of (small) hydropower, although it has proven to be difficult to attract private sector funding. While FUNAE has identified small hydropower as a suitable technology for rural (off-grid) electrification, there has not yet been a large-scale roll out.

\section{South Africa}

Almost $90 \%$ of South Africa's electricity is generated in coal-fired power stations. Five (5) percent is provided by hydroelectric and pumped storage schemes. Currently, around $700 \mathrm{MW}$ installed hydropower capacity exist in the country (Barta, 2011). The national electrification rate stands at 81 $\%$, with rural areas covered for $63 \%$ (DoE, 2012).

In 2010, the Department of Energy launched its Integrated Resource Plan (IRP2010), which outlines the electricity generation mix until 2030. According to the Cabinet-approved 'policy adjusted development plan', $17.8 \mathrm{GW}$ renewable energy will be part of the energy mix in 2030. The main source of hydropower will come from imported electricity (5.2 GW by 2030), while local, small-scale hydropower shares an allocation of $125 \mathrm{MW}$ with landfill gas-based electricity (Department of Energy, 2011).

In March 2009, South Africa's energy regulator (NERSA) announced Renewable Energy Feed-In
Tariffs (REFIT) for a selected number of renewable energy technologies. Small-scale hydropower (between 1 and $10 \mathrm{MW}$ ) qualified for a REFIT of ZAR 0.94/kWh (approximately €0.074/US\$0.096) (NERSA, 2009). This was adjusted to ZAR 0.671/ kWh (approximately $€ 0.065 / \mathrm{US} \$ 0.089$ ) in 2011 (NERSA, 2011).

However, the REFIT was never implemented. In 2011, it was replaced by the Renewable Energy Independent Power Producer Procurement Programme (REIPPP), through which the government intends to procure $3.725 \mathrm{MW}$ of renewable energy. The programme will be implemented through a number of bidding windows, with an allocation of $75 \mathrm{MW}$ for small hydropower (Department of Energy, 2011).

\section{Hydropower potential}

Although not well-documented, small-scale hydropower played an important role in providing South Africa's urban and rural areas with energy. The first electricity to cities like Cape Town and Pretoria came from small-scale hydropower, while smaller towns started distributing electricity through isolated grids powered by small hydropower stations. However, many of these systems were decommissioned as the national electricity grid and its cheap, coal-generated power supply expanded. The Sabie Gorge hydropower station, with three $450 \mathrm{~kW}$ turbines, is an example of such a decommissioned facility. Commissioned in 1928 to serve the town of Sabie in Mpumalanga, the station was closed in 1964 after the area was connected to the national Eskom grid (Eskom, 2003).

After approximately 20 years of neglecting to develop the hydropower potential of the country, the first new grid-connected small hydropower station was commissioned in the Sol Plaatje Municipality in the Free State Province. A few other stations are currently at varying stages of development.

By the end of the 1990s, the CSIR, Eskom and the Department of Minerals and Energy developed the South African Renewable Energy Database (Muller, 1999), which reported on the available renewable energy resources in the country, including the potential for hydropower. A follow-up study detailed the hydropower potential for the Eastern Cape Province (Szewczuk et al., 2000).

In the 'Baseline Study on Hydropower in South Africa', Barta (2002) investigates the installed capacity and the potential for new developments. He concludes that double the present installed small hydropower capacity can be developed in the rural areas of the Eastern Cape, Free State, KwaZuluNatal and Mpumalanga. In a later publication, Barta (2011) cites new insights about the potential of small hydropower in South Africa by including the hydropower of water transfer and gravity-fed 


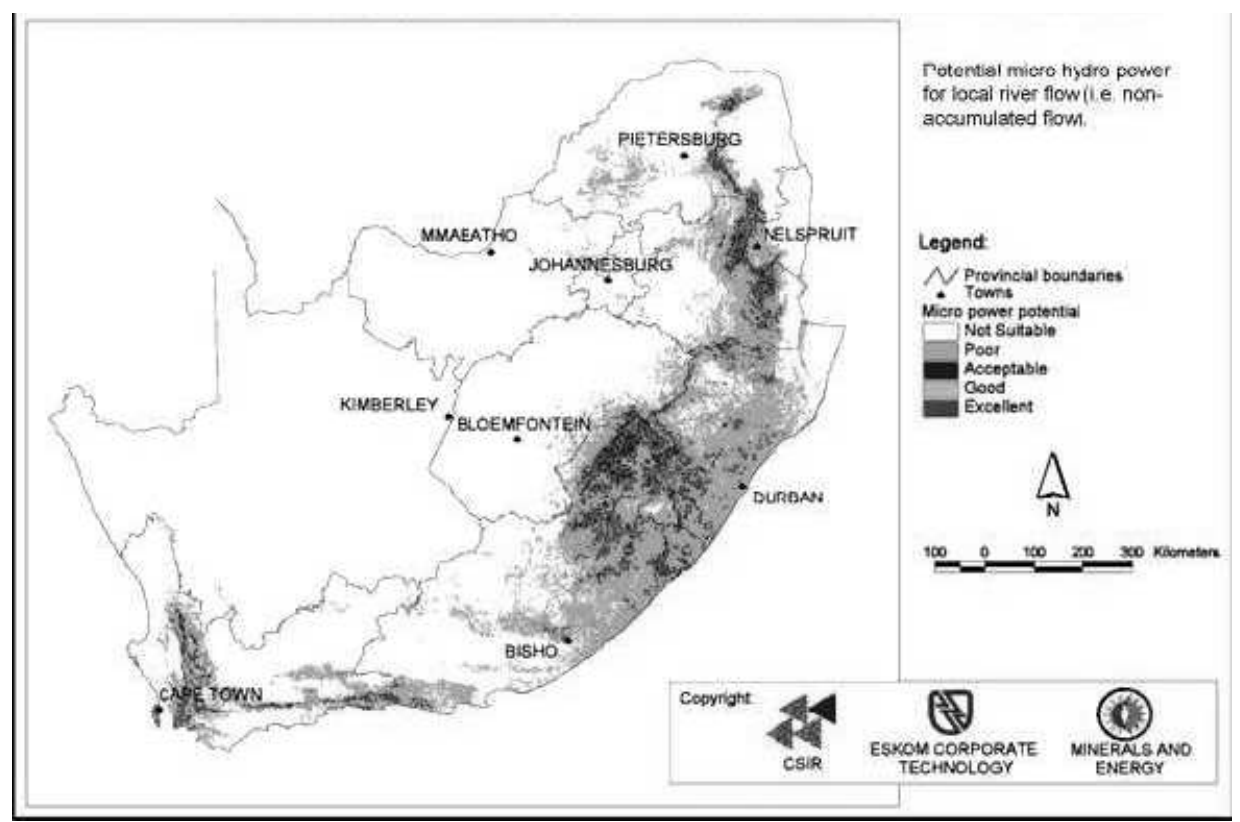

Figure 2: Micro hydropower potential in South Africa (Muller, 1999)

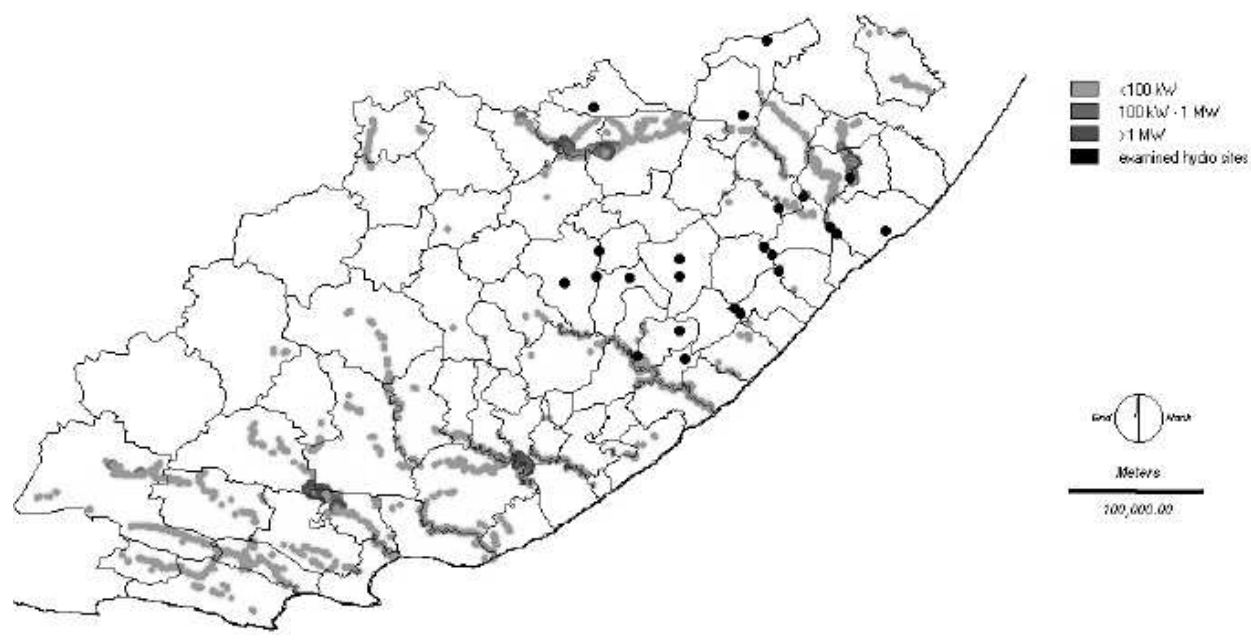

Figure 3: Small hydro potential in the Eastern Cape (Szewczuk et al., 2000)

water systems with a potential of $247 \mathrm{MW}$.

\section{Current systems}

Currently, Eskom operates four large (the $42 \mathrm{MW}$ Colley Wobbles, 360 MW Gariep, 11 MW Second Falls and 240 MW Vanderkloof stations) and two small hydropower stations (the $6 \mathrm{MW}$ First Falls and 1.6 MW Ncora stations). The Thaba Chweu Local Municipality owns a grid-connected station (the 2.6 MW Lydenburg station), while the private sector owns four stations connected to the national grid (the $300 \mathrm{~kW}$ Clanwilliam, 2 MW Freidenheim, 4 MW Merino and 3 MW Sol Plaatje stations).

A substantial number of micro and pico hydropower systems can be found in the KwaZuluNatal and Eastern Cape provinces. These systems primarily supply individual farms without providing electricity to neighbouring communities.

Little attention has been given to the use of hydropower for rural off-grid electrification, although considerable potential for this exists in the Eastern Cape. A pilot by Eskom to supply hydropower generated electricity to five remote schools in the late 1990s was not replicated at other sites (Gentles, 1998).

South Africa has a number of existing, inactive small-scale installations that could be refurbished, such as Belvedere (2.1 MW), Ceres (1 MW), Hartbeespoort (5.7 MW), Teebus (7 MW) and others (Barta, 2011).

A separate segment of hydropower is the application of in-flow turbines in water transfer systems. 
Table 3: Hydropower in South Africa

(For station details see http://hydro4africa.net/HP_database/country.php?country=South Africa)

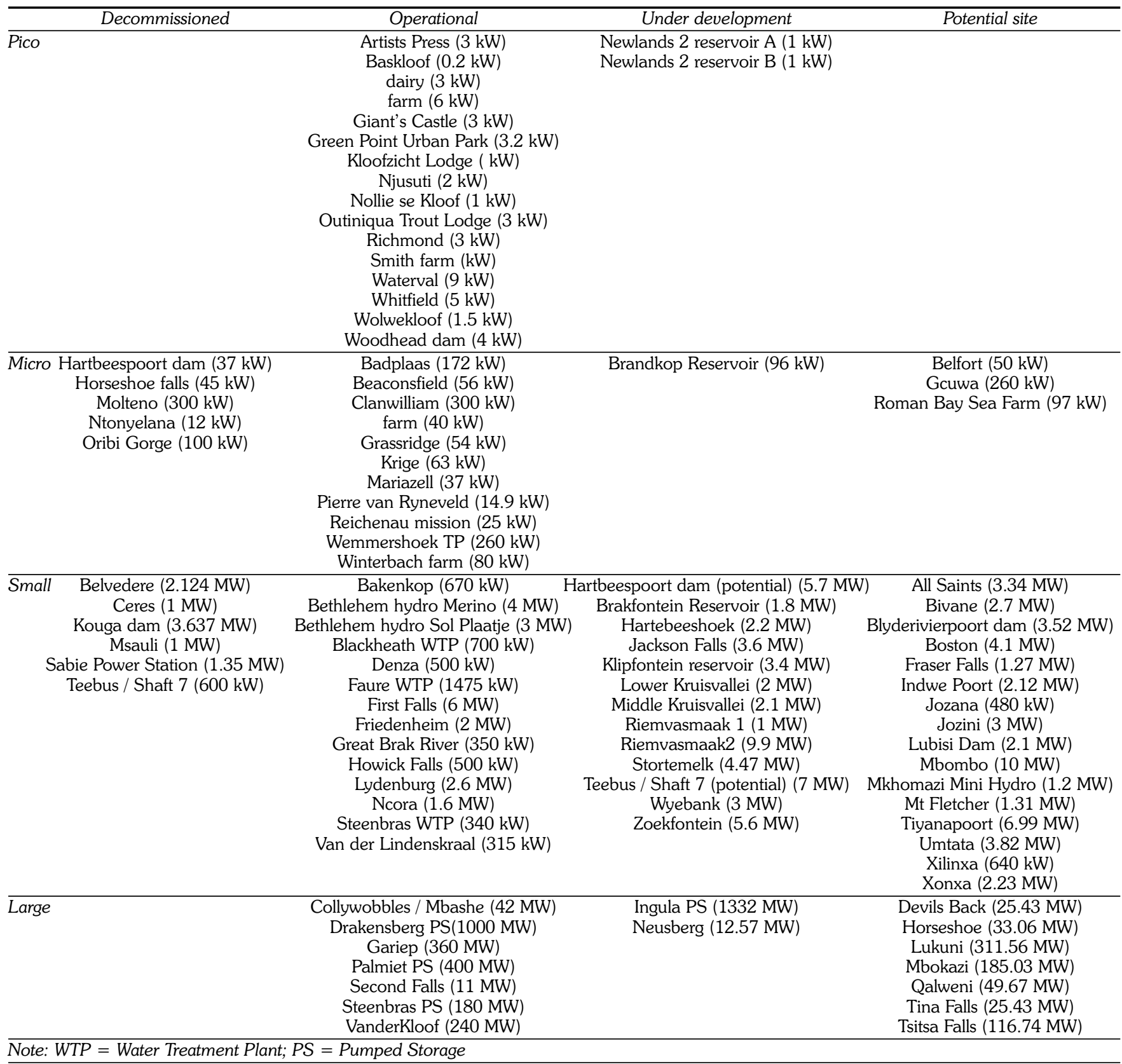

The City of Cape Town is operating hydropower turbines at four of its water treatment plants (the $700 \mathrm{~kW}$ Blackheath, $1.475 \mathrm{MW}$ Faure, $340 \mathrm{~kW}$ Steenbras and $260 \mathrm{~kW}$ Wemmershoek plants), while eThekwini is developing six sites, Rand Water another four sites at their infrastructure and Bloemwater a small system to power their head offices. A $15 \mathrm{~kW}$ pilot system was installed at the Pierre van Ryneveld reservoir in Pretoria as part of a University of Pretoria research project (Kotze, 2011).

Future for small hydropower

The future of small hydropower in South Africa consists of two main parallel tracks: IPP-developed grid-connected projects that feed into the national electricity system and small-scale systems for private use that do not feed into the grid (irrespective of the availability of a grid connection). Currently, no support is available for isolated systems for rural electrification purposes, although the government is currently reviewing its rural electrification strategy.

The future of grid-tied systems is closely linked to the government's policy on renewable energy development. The allocation in the IRP2010 and the REIPPP of $75 \mathrm{MW}$ small hydropower generation is less than the estimated potential of 1100 MW by 2030 (SESSA, 2010) and might therefore limit small hydropower development. The second round of REIPPP provided two hydro developers with preferred bidder status: the Neusberg plant of 
Kakamas Hydro Electric Power and the Stortemelk plant of NuPlanet (4.47 MW). Although the Neusberg site has a potential of $12.57 \mathrm{MW}$, only 10 MW will be developed in order for it to qualify under the REIPPP (DoE, 2012; Mulilo, 2012).

Several developers have indicated that they are preparing hydropower projects for the third round of REIPPP, which closes in August 2013. Unfortunately, small hydropower systems of between 1 and $5 \mathrm{MW}$ seem to be excluded from the REIPPP's small projects window due late 2013.

\section{Swaziland}

Approximately $80 \%$ of Swaziland's electricity is imported from South Africa. The remaining $20 \%$ of the electricity requirement is generated by hydropower. The overall electrification rate is estimated at $27 \%$, with $40 \%$ urban and $4 \%$ rural areas electrified.

Swaziland's power is supplied and distributed by the Swaziland Electricity Company (SEC), which owns the majority of the country's power stations and has the monopoly on the import, distribution and supply of electricity via the national power grid. The country has five privately-owned power stations and a substantial amount (almost 25\%) of energy used in the Kingdom is supplied by self-generators (Reegle, 2011).

\section{Hydropower potential}

The first hydropower station in Swaziland was a $52.5 \mathrm{kVA}$ turbine installed at Mlilwane and operated by James Weighton Reilly to separate tin from iron at the Mlilwane Tin Mine. Reilly later installed this plant on the Mbabane River to supply light to Mbabane. Since then several public and private hydropower plants have been installed, as well as hydraulic ram pumps to provide water for steam locomotives at the Ngwenya mine (REASWA, 2004).

Several studies have estimated Swaziland's hydropower potential. In 1970, a UNDP-funded study by Engineering and Power Development Consultants identified 21 possible sites for hydropower schemes (UNDP / WB ESMAP, 1987). Based on existing information, the Environmental
Centre for Swaziland estimates that the country has a gross theoretical potential of $440 \mathrm{MW}$ and a technically exploitable potential of $110 \mathrm{MW}$, of which 61 MW is economically exploitable (ECS, 2004).

In 2001 Knight Piesold Consulting carried out a comprehensive study on Swaziland's hydropower potential and estimated a potential of $8 \mathrm{MW}$ for micro and mini hydropower (Knight Piésold Consulting, 2001).

\section{Current systems}

Currently only five hydropower stations are operational: two in the small hydropower and three in the large hydropower range. The SEC operates the grid connected Edwaleni (15 MW), Ezulwini (20 MW), Maguduza (5.6 MW) and the Maguga (19.2 MW) installations. In December 2010, the SEC decommissioned the small-scale $500 \mathrm{~kW}$ Mbabane station, built in 1954, due to unprofitability (SEC, 2011).

A 1987 UNDP/ESMAP study of Swaziland's energy sector identified approximately $1 \mathrm{MW}$ of non-utility hydropower generation capacity (UNDP ( WB ESMAP, 1987), while it appears that only the $800 \mathrm{~kW}$ system of Swaziland Plantations is still in operation (REASWA, 2004).

\section{Future for small hydropower}

Several studies have been done to quantify Swaziland's hydropower resources. Although reforms within the country's electricity sector created the legal framework for introducing independent power producers (IPPs), no IPPs in the hydro sector have been initiated.

Current interest in large hydropower, e.g. the 120 MW Ngwempisi cascading scheme and the Lower Maguduza plant, potentially operated by IPPs, might pave the way for investments in small hydropower (Merwe, 2009).

In addition, the current rising retail price of electricity and a reduced reliability of the national grid have resulted in owners of old defunct hydropower plants considering rehabilitation. Except for anecdotic evidence of such initiatives like the Emafini microhydro system $(50 \mathrm{~kW})$ at the outskirts of Mbabane, no overview of potential sites unfortunately exists.

Table 4: Hydropower in Swaziland

(For station details see http://hydro4africa.net/HP_database/country.php?country=Swaziland)

\begin{tabular}{|c|c|c|c|c|}
\hline & Decommissioned & Operational & Under development & Potential site \\
\hline \multicolumn{5}{|l|}{$\overline{P i c o}$} \\
\hline \multicolumn{5}{|l|}{ Micro } \\
\hline Small & Mbabane (500 kW) & $\begin{array}{c}\text { Maguduza (5.6 MW) } \\
\text { Swaziland Plantations }(800 \mathrm{~kW})\end{array}$ & & Mnjoli (1.5 MW) \\
\hline Large & & $\begin{array}{l}\text { Edwaleni (15 MW) } \\
\text { Ezulwini (20 MW) } \\
\text { Maguga (19.2 MW) }\end{array}$ & & $\begin{array}{c}\text { Lower Maguduza (20 MW) } \\
\text { Ngwempisi (120 MW) }\end{array}$ \\
\hline
\end{tabular}




\section{Zimbabwe}

The 1990 MW installed electricity capacity in Zimbabwe consists of hydropower $(57 \%)$ and thermal electricity (43\%). National access to electricity is estimated at nearly $40 \%$, but rural access to electricity stands much lower at only about $19 \%$ (Reegle, 2011).

Aligned with Government policy to reform the electricity sector, a new Electricity Act was promulgated in 2002 to restructure and unbundle the Zimbabwe Electricity Supply Authority (ZESA) into separate successor generation, transmission \& distribution and service companies.

The new Act facilitated the creation of the Zimbabwe Electricity Regulator Commission (ZERC) as an autonomous regulatory body to encourage new investment in the electricity sector through appropriate regulatory, fiscal and environmental frameworks (MOEPD. 2009).

\section{Hydropower potential}

The hydropower potential of the Zambezi River for Zimbabwe and Zambia is 7200 MW. Each country has developed $750 \mathrm{MW}$ at Lake Kariba. A further 4 200 MW can be developed jointly with Zambia on Batoka Gorge, Devils Gorge, Kariba Extension and Mupata Gorge. There is a potential of $120 \mathrm{MW}$ of small and mini hydropower, consisting of $20 \mathrm{MW}$ from existing dams, $60 \mathrm{MW}$ from proposed dams and $43 \mathrm{MW}$ from run-of-river sites (Min Conf Water for Agriculture and Energy in Africa, 2008).

\section{Current systems}

Three small hydro plants are currently connected to the national grid: the $750 \mathrm{~kW}$ Rusito Scheme in the Chimanimani area and the Pungwe and Nyamhingura system in the Honde Valley. Other small hydropower plants are installed at Aberfoyle $(35 \mathrm{~kW})$, Claremont $(250 \mathrm{~kW})$, Kwenda $(75 \mathrm{~kW})$, Mutsikira (3 kW), Nyafaru (20 kW), Sithole-Chikate (30 kW) and Svinurai (10 kW) (Mbohwa, 2002).

The Masvingo Rural District Council approved a US\$ 13 million $5 \mathrm{MW}$ small hydropower project at Lake Mutirikwi recently. The application was made by the Great Zimbabwe Hydro-Power Company, which is jointly owned by Zimbabwean ZOL and South African NuPlanet. Another $5 \mathrm{MW}$ facility at Tokwe-Murkosi is planned for completion in 2013 (ESI-Africa, 2012).

The Great Zimbabwe Hydro plant will be situated on the 52-year-old, $63 \mathrm{~m}$ crested Mtirikwi Dam near Masvingo and will consist of a 5 MW Francis turbine. Project closure was expected by mid-2012, followed by construction before year-end. The delicate hydrology of the site required intense interaction between the developers and downstream water users. The expectation is that the project will form part of a CDM Programme of Activities for small hydropower in southern Africa (ESI-Africa 2012; Wat, 2012).

Detailed plans exist for the Manyuchi Dam hydropower plant, where two $350 \mathrm{~kW}$ turbines are envisaged (UNFCCC, 2000).

Ngangani Renewable Energy developed the 1.1 MW Nyamhingura hydropower plant in the Honde Valley in the Eastern Highlands and recently commissioned the 2.75 MW Pungwe plant. Ngangani has a license to develop 18 MW hydropower capacity, of which the 2.8 MW Duru plant is expected to start operation mid 2013 (Manayiti 2012, ZERC 2011, Eaton, Stanic 2013).

Future of small hydropower

The improved economic and political situation in Zimbabwe and the government's support for IPPs has given impetus to the development of small hydropower. In fact, the national regulator has licensed 16 IPPs with a combined generation capacity of more than triple ZESA's capacity. Three of the IPPs will use hydropower (Nkala. 2012; Gumbo, 2011).

\section{Mechanisms used for development of small hydropower}

The five countries described in this paper have all followed a different route towards the development of small and micro hydropower.

Table 5: Hydropower in Zimbabwe

(For station details see http://hydro4africa.net/HP_database/country.php?country=Zimbabwe)

\begin{tabular}{|c|c|c|c|c|}
\hline & Decommissioned & Operational & Under development & Potential site \\
\hline$\overline{P i c o}$ & & $\begin{array}{l}\text { Mutsikira }(3 \mathrm{~kW}) \\
\text { Svinurayi }(10 \mathrm{~kW})\end{array}$ & & \\
\hline Micro & Kuends (75 kW) & $\begin{array}{c}\text { Aberfoyle }(35 \mathrm{~kW}) \\
\text { Chipendeke }(30 \mathrm{~kW}) \\
\text { Claremont Hydro }(250 \mathrm{~kW}) \\
\text { Nyafaru }(20 \mathrm{~kW}) \\
\text { Sithole Chikati }(30 \mathrm{~kW})\end{array}$ & & \\
\hline Small & & $\begin{array}{c}\text { Nyamhingura Hydro (1.1 MW) } \\
\text { Pungwe A }(2.6 \mathrm{MW}) \\
\text { Rusitu }(750 \mathrm{~kW})\end{array}$ & $\begin{array}{c}\text { Duru (2.8 MW) } \\
\text { Great Zimbabwe Hydro (5 MW) }\end{array}$ & Manyuchi Dam (700 kW) \\
\hline
\end{tabular}


In South Africa, a number of grid-connected hydro systems are operating with a mix of utility owned and managed systems, municipal owned and contract managed systems and privately owned and operated systems. Individual farmers own and operate a substantial number of pico and micro systems, either completely off-grid or to supplement grid power. With the required policy support lacking, no off-grid systems are used for rural electrification.

In Lesotho, all small and micro hydropower developments are linked to government entities. Only one of the operational hydro stations is used for remote rural electrification in a hybrid hydro/diesel island operation. A number of players have shown interest in operating hydropower as IPPs, but there is scant evidence of actual progress.

In Swaziland, small hydropower used to play an important role in self-generation, but currently only one private hydropower station is still in operation. The national utility operates a number of hydropower stations but recently decommissioned the smallest station. A number of initiatives are ongoing to attract private sector involvement in developing new hydropower to feed into the national grid.

Mozambique's national electrification agency, FUNAE, and a number of NGOs and donors are the main drivers of small hydropower developments. The government regards it as an important contribution to (off-grid) electrification but is challenged to find the best implementation model. Practical Action and GIZ, with their local partners, are capitalising on the success of private entrepreneurs offering milling services to establish localised mini grids for electrification.

In Zimbabwe, the interest from local and international NGOs in isolated small hydropower was augmented recently by private sector interest in developing small hydropower as IPPs to feed into the national grid.

In all five countries, a range of stakeholders from policy makers to developers are showing a renewed interest in small hydropower. In South Africa and Swaziland, the government and power utility focus on grid-connected small hydropower has resulted in off-grid applications for individual households and businesses only and not for rural electrification purposes. Lesotho followed a government-led development of small hydropower and the use of off-grid electrification technology. In Zimbabwe and Mozambique, government attention is on grid-connected and off-grid systems, while the two countries are implementing different delivery/implementation models.

\section{Conclusions}

Although different models were followed, all five countries covered in the paper do currently see activities around grid connected small scale hydropower. Particular frameworks that facilitate IPPs and Power Purchase Agreements with the national utility do provide a basis for (local) commercial banks to provide finance.

Off-grid hydropower for rural electrification purposes sees activities in the countries with an active (support) role of government in this respect only. None of the utilities in the countries covered in the paper is operating small hydropower stations for off-grid electrification, except for LEC in Lesotho (but only so after privatisation or private sector operation did not succeed).

While grid connected small hydropower is mostly build and operated by either national utilities or IPPs, greater deployment of small hydropower for off-grid electrification purposes in the region will require different implementation models. Specific attention to sustainable financing and business models is required to facilitate the development of off-grid small hydropower in the region.

\section{References}

Barta, B., (2011). Renewable energy: hydropower. In: E. Kiderlen, B. Bredenkamp and L. Smith, eds, The Sustainable Energy Resource Handbook. South Africa, Volume 2. The Essential Guide. Cape Town: Alive2green, pp. 139-139-151.

Barta, B., (2002). Capacity building in energy efficiency and renewable energy. Baseline study - hydropower in South Africa. Pretoria.

Chambal, H., (2010). Energy Security in Mozambique. Series on Trade and Energy Security - Policy Report 3. Winnipeg: International Institute for Sustainable Development.

Department of Energy, (2011). Integrated Resource Plan for electricity 2010-2030, Revision 2, Final Report. IRP2010. Pretoria: Department of Energy.

Department of Energy, (2011). IPP Website. Available: http://www.ipp-renewables.co.za/index.php/about (Feb 29, 2012).

DOE, (2012). Announcement of Preferred Bidders of the IPP Procurement Programme - Window 2. Available:

http://www.ipprenewables.co.za/\#/blog/post/view/isAj axRequest/true/id/181 (May 25, 2012).

DOE, (2012). Unpublished electrification statistics.

Eaton, A. and Stanic, G., (2013). Water to wire environmentally and socially sustainable small hydro power plants in Zimbabwe, Clean Power Africa 20132013.

ECS, (2004). Last update, Environmental Indicators for Swaziland - Energy. Available:

http://www.ecs.co.sz/indicators/natural_resources_ene rgy.htm (April 26, 2012).

ESHA and IT POWER, (2006). Small hydropower for developing countries. Brussels: European Small Hydropower Association.

ESI-AFRICA, (2012). New hydroelectric plant for Zimbabwe. Available: http://www.esiafrica.com/node/14186 (Feb 29, 2012). 
Eskom, (2009). Eskom heritage: Electricity in South Africa - the early years. Available: http://heritage.eskom.co.za/heritage/electricity_in_sou th_africa.htm (February 29, 2012).

Eskom, (2003). Sabie River Power Station. Available: http://www.eskom.co.za/heritage/sabie/sabie.htm (December 13, 2003).

Esser, L., (2012). A global overview. Water Power \& Dam Construction, 64, pp. 18-18-20.

Fraenkel, P., Paish, O., Bokalders, V., Harvey, A., Brown, A. and Edwards, R., (1991). Micro-hydro power, a guide for development workers. London: Intermediate Technology Publications Ltd.

Gaul, M., Kölling, F. and Schröder, M., (2010). Policy and regulatory framework conditions for small hydro power in Sub-Saharan Africa. Eschborn: EUEI PDF.

Gentles, G., (1998). Provision of basic lighting in schools in non-electrified areas of South Africa, Domestic Use of Electrical Energy Conference 1998 1998, pp. 203-206.

Government of Lesotho, (2005). Vision 2020. Maseru.

Grongstad, S., (2008). Mantsony'ane hydropower plant after flooding November 2006 - draft report - diagnostic study. Tunis: African Development Bank.

Gumbo, L., (2011). Last update, Zimbabwe: 13 New Power Stations Get Nod. Available: http://allafrica.com/stories/201109120012.html (September 30, 2012).

IEA, (2009). World Energy Outlook 2009. Paris: IEA.

IEA, (2003). Renewables for power generations. Status $\&$ prospects. Paris: IEA.

IRENA, (2012). Country Case Study Renewables Readiness Assessment: Mozambique Preliminary findings. Abu Dhabi: IRENA.

ITDG, (2006). Report on the scoping study for micro hydro investments in Mozambique.

Jackson, B. and Johnson, M., (1982). Lesotho: recommended activities in small hydropower development. Washington: National Rural Electric Cooperative Association

Jonker Klunne, W.E., (2011). Small hydro in Africa. International Water Power and Dam Construction, 63, pp. 14-14-15.

Khennas, S. and Barnett, A., (2000). Best practices for sustainable development of micro hydro power in developing countries. Washington.

Klunne, W., (1993). Hydro-power end-uses at Svinurayi co-operative (Cashel Valley, Eastern Highlands, Zimbabwe), University of Twente, Enschede, the Netherlands.

Knight Piésold Consulting, (2001). Report on hydropower potential. Final report. Knight Piésold Consulting.

Kotze, P., (2011). The potential of small hydropower plants in South Africa. WaterWheel, 10 (November/December 2011), pp. 18-19, 20.

KPMG, (2008). Policy for Renewable Energy and Master Plan for Off-Grid Energy Phase II.

Manayiti, O., (2012). Hydro-electricity project to ease power problems. Available: http:/www.newsday.co.zw/article/2012-04-24-hydroelectricity-project-to-ease-power-problems/ [September 30, 2012].

Mbohwa, C., (2002). Zimbabwe: An Assessment of the
Electricity Industry and What Needs to Be Done. The Electricity Journal, 15(7), pp. 82-91.

Merwe, C.V.D., (2009). Swaziland studies 120-MW hydropower plant. Engineering News, 29.

Michael, E.G.,(2008). Institutional Design and Practices for Sustainable Decentralised Energy Systems Development for Rural Electrification. The Case of Isolated Mini-Hydro Power Systems Developed by Catholic Church Mission, Njombe Diocese, Tanzania, University of Twente, Enschede, the Netherlands.

Min Conf Water for Agriculture and Energy in Africa, (2008). Hydropower resource assessment of Africa. Sirte: Water for Agriculture and Energy: the challenges of climate change.

Min Conf Water for Agriculture and Energy in Africa, (2008). National Investment Brief Zimbabwe. Sirte: Water for Agriculture and Energy: the challenges of climate change.

MOEPD, (2009). Investment Opportunities in Zimbabwean Energy Sector. Available: Investment Opportunities in Zimbabwean Energy Sector (06/11, 2012).

Mtalo, F., (2005). Small scale hydropower for rural development. Nile Basin Capacity Building Network NBCBN Research cluster.

MULILO, 2012. Neusberg PDD.

Muller, J., 1999. South African renewable energy resource database. Chapter 2 Modelling hydro power potential. ENV/P/C/98161. Pretoria: CSIR.

Mutubuki-Makuyana, C.S.(2010). Financial and Ownership Models for Micro-hydro Schemes in Southern Africa. Boiling Point, (58), pp. 40.

NERSA, (2011). NERSA Consultation Paper- Review of Renewable Energy Feed - In Tariffs. Pretoria: NERSA.

NERSA, (2009). NERSA decision on renewable energy feed-in tariff (REFIT). Pretoria: NERSA.

Nkala, O., (2012). Powering Up: Three more IPPs licensed in bid to plug big Zimbabwe power gap. Engineering News, , pp. 21.

Pigaht, M. and Van der Plas, R.J., (2009). Innovative private micro-hydro power development in Rwanda. Energy Policy, 37(11), pp. 4753-4760.

REASWA, (2004). Renewable Energy in Swaziland. Case Study Brochure 2004. Mbabane: Ministry of Natural Resources and Energy, Swaziland Government.

REEGLE, (2011). Country Energy Profile: Mozambique. Available: http://www.reegle.info/countries/mozambique-energy-profile/MZ (May 22, 2012).

REEGLE, (2011). Country Energy Profile: Swaziland. Available: http://www.reegle.info/countries/swazilandenergy-profile/SZ [March 30, 2012].

REEGLE, (2011). Country Energy Profile: Zimbabwe. Available: http://www.reegle.info/countries/zimbabwe-energy-profile/ZW (March 30, 2012).

SAD-ELEC, PPA, ECON, DIALOG, UCSA and SECHABA, 2001. Access to electricity study - final report.

SAD-ELEC, PPA, ECON, DIALOG, UCSA and SECHABA, (2001). LEC Hydro Generation Station: Review and Recommendations.

SEC, (2011). Annual Report 2010/11. Mbabane: Swaziland Electricity Company. 
SESSA, (2010). IRP2010 Comment and Input: SESSA Hydro Interest Group.

Szewczuk, S., Fellows, A. and van der Linden, N., (2000). Renewable energy for rural electrification in South Africa. European Commission FP5 JouleThermie Programme.

Taele, B.M., Mokhutšoane, L. and Hapazari, I., (2012). An overview of small hydropower development in Lesotho: Challenges and prospects. Renewable Energy, 2012(1).

UNDP / WB ESMAP, (1987). Swaziland: Issues and Options in the Energy Sector. 6262-SW. UNDP /WB ESMAP.

UNFCCC, (2000), Assessment of the E7 Group (including EDF) Proposal for a Mini-hydroelectric Power Station in Zimbabwe. Available: http://unfccc.int/kyoto_mechanisms/aij/activities_impl emented_jointly/items/1886.php (February 29, 2012).

Villa, J.P., (2012). Draft plan for Chimoio's Excellence Center Hydropower Division, Carl von Ossietzky University Oldenburg.

WAT, S.V.D., (2012). Developing small scale hydro in Southern Africa - a road map and case studies, hidroenergia 20122012.

World Bank, (2010). Energy Strategy Approach Paper. Washington: World Bank Group / Sustainable Development Network.

ZERC, (2011). ZERC presentation at Naruc Workshop, 2011.

Received 3 December 2012; revised 8 July 2013 